\title{
Plant extinction excels plant speciation in the Anthropocene
}

\author{
Jian-Guo Gao ${ }^{1 *} \mathbb{D}$, Hui Liư ${ }^{2}$ Ning Wang ${ }^{3}$, Jing Yang ${ }^{4}$ and Xiao-Ling Zhang ${ }^{5}$
}

\begin{abstract}
Background: In the past several millenniums, we have domesticated several crop species that are crucial for human civilization, which is a symbol of significant human influence on plant evolution. A pressing question to address is if plant diversity will increase or decrease in this warming world since contradictory pieces of evidence exit of accelerating plant speciation and plant extinction in the Anthropocene.

Results: Comparison may be made of the Anthropocene with the past geological times characterised by a warming climate, e.g., the Palaeocene-Eocene Thermal Maximum (PETM) 55.8 million years ago (Mya) - a period of "crocodiles in the Arctic", during which plants saw accelerated speciation through autopolyploid speciation. Three accelerators of plant speciation were reasonably identified in the Anthropocene, including cities, polar regions and botanical gardens where new plant species might be accelerating formed through autopolyploid speciation and hybridization.

Conclusions: However, this kind of positive effect of climate warming on new plant species formation would be thoroughly offset by direct and indirect intensive human exploitation and human disturbances that cause habitat loss, deforestation, land use change, climate change, and pollution, thus leading to higher extinction risk than speciation in the Anthropocene. At last, four research directions are proposed to deepen our understanding of how plant traits affect speciation and extinction, why we need to make good use of polar regions to study the mechanisms of dispersion and invasion, how to maximize the conservation of plant genetics, species, and diverse landscapes and ecosystems and a holistic perspective on plant speciation and extinction is needed to integrate spatiotemporally.
\end{abstract}

Keywords: Anthropocene, Biodiversity, Conservation, Plant extinction, Plant speciation

\section{Background}

Today, humans are the dominant animal species on Earth, and we have both a direct (dramatically changing land surfaces by settlements) $[1,2]$ and indirect influence on the Earth's climate [3-5], consequently changing the physiology, behaviour, and evolution trajectories of all other organisms [6-9]. The impact of climate warming is so strong that it influences almost

\footnotetext{
* Correspondence: gaojg@pku.edu.cn

'Department of Ecology, College of Urban and Environmental Sciences, and Key Laboratory for Earth Surface Processes of the Ministry of Education, Peking University, No.5 Yiheyuan Road Haidian District, Beijing 100871, China Full list of author information is available at the end of the article
}

everything from microorganisms to plant and animal populations. Climate change accelerates plant extinction by changing their phenology, e.g., mismatching the flowering period of plants with pollinating time of insects $[10,11]$ and narrowing the range of physiological adaptation, thus reducing plant resistance to extreme weather events $[12,13]$. These effects are particularly substantial in hotspot areas of plant diversity in the tropics and subtropics [14-19]. On the other hand, climate warming has led to increased global vegetation activity, providing more resources and better hydrothermal conditions which are necessary for the evolution of new species $[8$, 20-24]. Recently, it has been observed that the plant 
diversity at a mountaintop increased significantly under the influence of climate warming [25], and studies have also showed that plant diversity continued to increase at high latitudes [26], leading to the conclusion that the Anthropocene is and will continue to be the golden age for the evolution of new species. The accelerated plant speciation in natural and unnatural ecosystems during this or the following centuries [23, 27-30] means that we will witness a world of diverse plants thriving in new environmental conditions. The two abovementioned viewpoints propose contrasting scenarios, i.e., the first indicates that plant speciation is accelerating in the Anthropocene, whereas the second indicates that plant extinction is simultaneously accelerating. The question that is important to address is if plant diversity will increase or decrease in this and following centuries [9].

Considering the development and utilization of plant resources, during the last 10,000 years, we have gradually acquired immense knowledge of plant species. Since the end of the Last Glacial Maximum, the Earth's climate has warmed. The establishment of human settlements led to the development of agriculture and consequently, the development of modern civilization. Agriculture is a symbol of human civilization [31] and it is inseparable from plant domestication. Today, steamed bread made from hexaploid wheat, triploid banana, and seedless watermelons are consumed daily throughout the world, oils are extracted from tetraploid peanuts and clothing is made from tetraploid cotton. Domesticated plants, which some of them are polyploids, have higher leaf nitrogen content, higher growth rate and bigger seeds than those of their diploid ancestors, as polyploids with larger genome sizes are more resistant to adverse effects of genetic mutations [32, 33]. Today, the cultivation and management of polyploid crops support a population of 7.7 billion. Polyploid species generally evolve as a consequence of doubling of the chromosomes of the ancestral diploid. In recent times, the technology of inducing neopolyploidy by physical and chemical agents has been developed and is used in research. However, the technology used today for developing new polyploids is essentially the same as polyploidization in nature, except that the breeding cycle is greatly shortened using novel methods [34]. Compared with the human technology for developing neopolyploids, in nature, new species often evolve because of climate or environmental changes [29, $34-36]$.

\section{The dominant plant speciation type in nature}

Even though humans have been breeding new plant species for the past few thousand years, more focus has been placed on plant extinction than on plant speciation (Fig. 1) [37]. With the acceleration of climate warming, plant speciation caused by warming climate may become a more common phenomenon in this and following centuries [27]. Human civilization supports itself by intensive exploitation and utilisation of fossil energy accumulated approximately 300 million years ago (Mya). The $\mathrm{CO}_{2}$ emissions from a large number of fossil combustions are the main factor contributing to warmer climate and associated issues, such as ocean acidification and species extinction. Species extinction and conservation are important matters of public concern (Fig. S1). Comparing the extinction risk of species, the formation of new plant species is thought to be currently constrained in the academic world [27], this is partly because people (non-scientists) become aware of species extinction reports (Fig. 1; Fig. S1). However, plant speciation through polyploidization may be quite common, and autopolyploidy, which is caused by the polyploidization of two conspecific individuals, is presumed to be the dominate [27, 28, 34] (Fig. 2). On the other hand, allopolyploids are the result of interspecific hybridization process and chromosome duplication. Speciation as a consequence of chromosomal rearrangements, homoploid hybrid speciation, and lineage splitting are not common because of their long evolutionary time and low occurrences, e.g., it takes several thousand years for a new plant species to evolve through lineage splitting [39].

\section{Speciation accelerated by the greenhouse effect}

Understanding that autopolyploid speciation is the most dominant speciation type in the Anthropocene requires a view from the perspective of plant evolution. The Earth has experienced extensive climatic fluctuations since its birth. The first plants are nearly omnipresent on Earth and they often survive climatic fluctuations via whole genome duplication, i.e., polyploidization [35]. For example, many species of ferns, gymnosperms, and angiosperms have undergone multiple whole genome duplications during their long evolution [40]. The main biological determinant of plant survival is their genome multiplication. For example, during the warm period of the Palaeocene-Eocene Thermal Maximum (PETM) 55.8 Mya, when the Earth experienced temperatures 5$8{ }^{\circ} \mathrm{C}$ higher than those today, the multiplication of the genomes of many angiosperm species occurred [38, 41, 42]. Multiplications provided angiosperms the advantage in surviving sudden climate changes by giving them a competitive growth advantage, and they were eventually established as the most successful plant lineage [36, 40, 43-47]. While climate warming could disturb germline development and lead to reduced fitness in some plant species [48], plants could also evolve to adapt because the production of unreduced gametes that facilitates autopolyploidization is positively correlated with nutrient (e.g., nitrogen deposition and crops fertilization), 


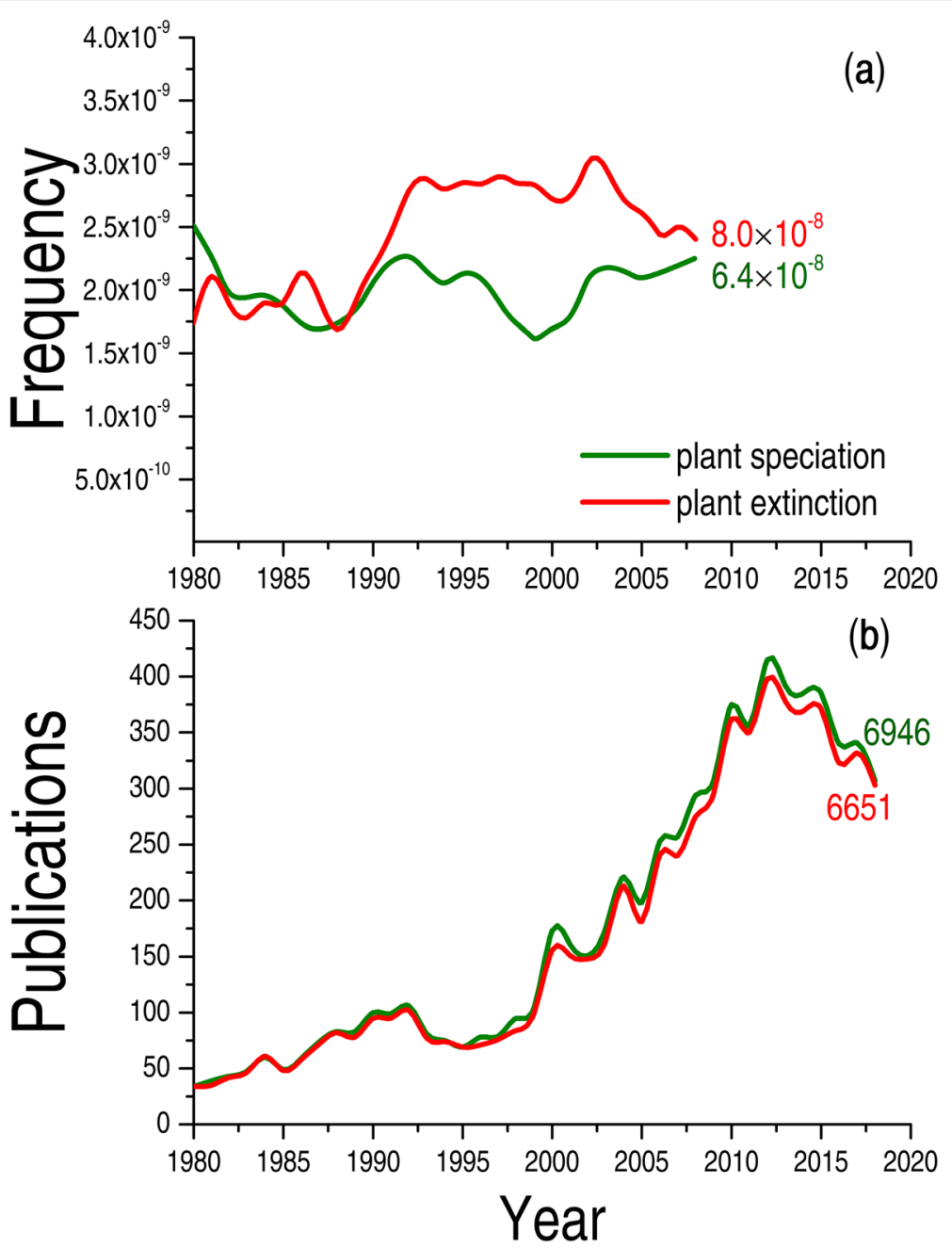

Fig. 1 Differences of public and scientific attention to plant speciation and extinction. The public is more concerned with plant extinction (a), whereas scientists have a greater interest in plant speciation (b). We used Google Ngram's millions of English-language books [37] to quantify the public attention on "plant speciation" and "plant extinction" during 1980-2008. The cumulative word frequency is $6.4 \times 10^{-8}$ and $8.0 \times 10^{-8}$ for plant speciation and extinction, respectively. We searched the core database of Web of Science for the publication of "plant speciation" and "plant extinction" during 1980-2018 to illustrate the academic concerns. The cumulative published papers are 6946 and 6651 on "plant speciation" and "plant extinction", respectively. The searched research field was plant science, and the selected 10 journals of evolution and ecology: Annual Review of Ecology Evolution and Systematics, Biology Letters, BMC Evolutionary Biology, Evolution, Evolutionary Applications, Evolutionary Biology, Evolutionary Ecology, Proceedings of the Royal Society B-Biological Sciences, Systematic Botany, and Trends in Ecology \& Evolution

humidity (e.g., floods and reduced surface runoff due to elevated $\mathrm{CO}_{2}$ ), temperature variation (e.g., heat waves) and high levels of herbivory (i.e., bark beetle and caterpillars outbreaks) that likely to be encountered under future climate change scenarios $[27,34]$. Considering that the climate at the end of this century could resemble that during PETM [49], and if greenhouse gas emissions are not significantly reduced, it is reasonable to infer that plants will experience polyploidy of a similar magnitude.

\section{Mechanisms underlying plant speciation}

Review the past to understand the present. According to the Representative Concentration Pathway 8.5 (RCP 8.5) emission scenario, climate warming today might promote polyploidy to a similar extent to that during PETM. The question is, what are the biological or ecological mechanisms underlying the increase in polyploidization? There are two possible reasons for this increase $[34,48]$ : (i) the first is high temperature induction of chromosome doubling. In a newly fertilized immature embryo or germ cell, active division occurs, meaning it is easy to induce polyploidy by sudden temperature increases (but not as high as to cause cell death). Autotetraploid corn was developed using this method prior to the discovery and extensive use of colchicine; (ii) Climate warming leads to the extension of 


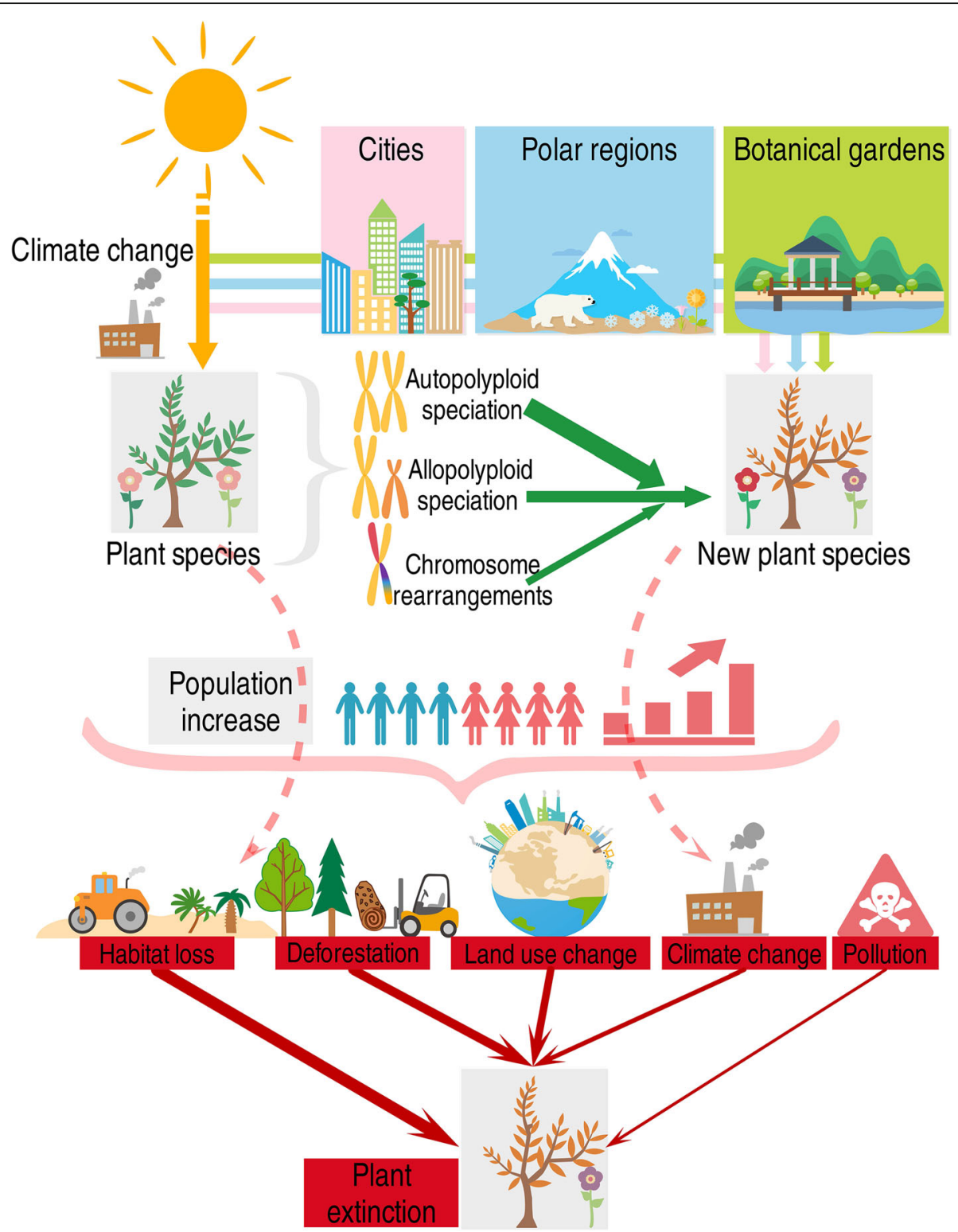

Fig. 2 A simplified conceptual model depicting the types of plant speciation and the drivers of plant extinction in the Anthropocene. Three identified plant speciation accelerators, i.e., cities, polar regions, and botanical gardens are illustrated to show how climate warming might change plant evolution in the future. The contribution to plant speciation displayed from the top to bottom are: autopolyploid speciation, allopolyploid speciation, and chromosomal rearrangements. The main drivers of plant extinction displayed from right to left are: habitat loss, deforestation, land use change, climate change, and pollution. The solid lines denote the biological and ecological processes of plant speciation and extinction, in which the green ones denote the corresponding speciation types, and the red ones denote the five drivers of plant extinction. The thickness of the arrow denotes the relative strength of the contributions. It should be noted that climate change accelerates plant speciation while drives plant extinction either, and human population increase as the primary driver of plant extinction. Both new plant species and their progenitors of plant species may face same extinction risk in the Anthropocene, but the new plant species are more likely to survive due to their stronger natural adaptability to climate change [38]

the growing season. This increases the chances of contacts among plants, and thus sympatric speciation emerges as the dominant speciation type [50]. Significant results of climate warming are the advance of budding and the delay in leaf shedding, both of which prolong the growing season [51]. These scenarios favour the breakage of prezygotic barriers. In the foreseeable future, climate warming will be the dominant climatic feature of this and the following centuries [52], thereby ensuring the occurrence of autopolyploid speciation [35].

\section{Accelerators of plant speciation}

Plant resources determine the sustainable development of human society, and thus, nearly all countries have 
made great efforts to establish protected areas to maintain their plant diversity $[53,54]$. A large number of protected areas worldwide have significantly reduced habitat loss [55-57], and large unexplored wilderness areas have reduced the risk of plant extinction by at least 50\% [58]. Compared to larger and more effective protected areas ( 15\%) [53] or wilderness ( 23\%) [59], urban development areas account for only $\sim 1 \%$ of land surface area [60], but they have extremely significant effects on plant phenology, physiology, ecology, and heredity [61-63]. In addition, the genetics of the plant species in botanical gardens are also significantly different from their wild congeners [64]. In the Anthropocene, the three accelerators that have a significant effect on driving plant species evolution are cities, the polar amplification of climate change, and botanical gardens which are believed to play both the role of "cradle" and "museum".

\section{Accelerator I: cities}

One of the most prominent features of the Anthropocene are man-made clusters of large buildings and cities. As a "natural laboratory", the city is an ideal environment for monitoring the rapid evolution of plants [65]. Cities are inhabited by more than $50 \%$ of the world's population and consume $\sim 80 \%$ of global energy [60]. As a consequence of the pronounced "heat island effect", it has been predicted that urban development will become an accelerator of plant speciation. The temperatures of most cities are $\sim 1{ }^{\circ} \mathrm{C}$ higher than those of the surrounding non-urban areas, and the temperatures in humid regions or densely populated cities can be even $1.5^{\circ} \mathrm{C}$ higher than those of the surrounding non-urban areas [66]. Therefore, the climate of cities today is comparable to the predicted climate at the end of the century (equivalent to significant carbon mitigation in the RCP 2.6 scenario). As most urban plant species are native species with strong adaptability [67, 68], and most importantly, because these native urban plants are planted and grown only in extremely limited space, these plants are more likely to undergo autopolyploid speciation than any other speciation type [65].

\section{Accelerator II: polar regions}

As a consequence of polar amplification [69], the Arctic may be the fastest warming region on Earth compared to the global average $\left(0.60\right.$ vs. $0.17^{\circ} \mathrm{C} /$ decade) [70]. Melting ice further reduces solar radiation reflections, which further accelerates the melting of glaciers, eventually leading to an ice-free summer predicted for the eve of 2030 [71-73]. The warm Arctic waters are favourable for phytoplankton [74], and the increase in phytoplankton significantly increases the primary producers' provision for marine animals, which in turn promotes the prosperity of biodiversity [75]. Polar regions (including Antarctica and the Qinghai-Tibet Plateau) have always been the centre of plant divergence [76, 77], and they may play more of a "cradle" role in the context of climate warming. It has recently been found that the number of plant species has significantly increased in the Arctic [26], which might have been a consequence of diffusion or migration [78] rather than speciation, suggesting a "museum" role of the polar regions. With the further warming of the global climate, especially in the Antarctic $[79,80]$ and the "Third Pole", i.e., QinghaiTibet Plateau [81] that have similar temperature increase amplitudes to the Artic, new species may evolve from alien and native species through hybridization or autopolyploid speciation in these polar regions.

\section{Accelerator III: botanical gardens}

Early plant gatherers collected exotic plants and planted them in small areas; today, these areas would be called botanical gardens. Botanical gardens are spread worldwide because of their practical functions, such as cultural and recreational function as well as medicinal plant preservation [82]. When plant gatherer Ernest Henry Wilson brought thousands of plant species from China and Asia to Kew Botanic Garden, he could not have known that his actions would inadvertently lead to the evolution of a new species, Primula kewensis [23], as well as many other new plant species (cf. Chris D. Thomas's papers). There is a possibility that some epiphytic orchids in the botanical garden are currently undergoing rapid speciation [64]. The attraction of people to ornamental flowers has led to the development of new species of orchids and primroses [83, 84], indicating that botanical gardens can be used as cradles of speciation. The main reason why botanical gardens are a major factor in the evolution of new species is that a large number of plants gathered in a small area increases the probability of interspecific pollen transmission via pollinating insects. Therefore, in addition to autopolyploid speciation, allopolyploidy and hybrid speciation are also important in plant evolution in these artificial gardens [23, 24, 29, 85-88]. Botanical gardens preserve $~ 30 \%$ of plant species and $\sim 40 \%$ of endangered plants on the Earth, and thus they have an extremely important conservation function [89]. One of the most obvious features is that the plants found in botanical gardens may have come from any corner of the world [90]. Therefore, the contribution of allopatric and that of sympatric speciation to the evolution of new species may be equally important.

\section{Bigger extinction}

\section{The alarming risk of extinction}

Polyploidy promotes genetic diversity, which is why it is a common plant strategy for surviving climate change 
[27]. The accelerated speciation under climate warming conditions enhances their adaptation and resilience to climate change, which is necessary to maintain plant biodiversity and crucial for survival. For example, fossil evidence suggests that plants were resilient to mass extinction [91], and had fewer extinctions compared to marine fauna. Under the climate warming scenario, the resulting accelerated plant speciation could be 50-300 times faster than background speciation, and this rate is far lower than the current rate of plant extinction. In contrast, the rate of plant extinction in the Anthropocene is 1000-10,000 times higher compared to that of the background extinction [27, 92]. Therefore, as a consequence of mankind's inconsiderate exploitation of the Earth's resources, as well as land-use changes, habitat loss and international trade $[9,93]$, the risk of plant extinction is much higher than the possibility of plant speciation (Fig. 2). For example, Marques et al. (2019) estimated that $33 \%$ of Central and Southern America and $26 \%$ of Africa's biodiversity were influenced by consumption in other world regions [93].

\section{The worsening tropics}

Although the risk of plant extinction in Europe (nontropical areas) is not high, and regional plant diversity may be increasing, the abundance of plant species in the tropical regions with highest species richness (i.e., Congo, Amazon, and Southeast Asia) [94] is decreasing and that's why the risk of global overall plant extinction still appears to be very high $[15,16,95]$. For example, $58 \%$ of tree species in Amazonia are predicted to go extinct in the following 30 years under the pressures of deforestation and climate change [94].

\section{Trophic cascading}

The indirect effects of anthropogenic activities may be more devastating to plants than we perceive. The annual decline in insect biomass is estimated to be $2.5 \%$ worldwide [96]. As insects are the basis of terrestrial and aquatic food chains, the increase in prezygotic barriers would be devastating for plant diversity [87]. For example, in some very small populations of endangered plants, the decrease in the number of pollinating insects can increase the pollen limit, thus increasing the risk of extinction $[97,98]$. The decrease in the number of pollinating insects negatively affects not only endangered plants, but almost all plants that are pollinated by insects, especially certain crops crucial for agriculture [99, 100]. In recent years, large-scale use of chemicals such as neonicotinoid pesticides has caused irreversible damage to bee populations [101-103]. Even worse, the dramatic decline in bird populations is similar to the dramatic decline in insect populations. For instance, a recent study showed that North American avifauna has decreased by 3 billion over the past half century, which is equivalent to $\sim 30 \%$ of the total number of birds in the 1970s [104]. Today, the sharp decline in bird populations as a consequence of habitat loss because of agricultural activities, urbanization, and toxic pesticide use in both breeding and wintering areas is a global problem $[105,106]$. Pollinating insects and birds are directly related to plant life histories (e.g., reproduction and seed dispersal), which is why their continuous and significant decrease in numbers will have a significant negative impact on plant diversity $[99,107-109]$.

Humans determine plants extinction directly and globally In the next ten years, the global population is predicted to reach 8.5 billion [110] and surge to 9.7 billion and 11 billion in the middle and the end of this century, respectively [111]. Such a large population will have significant impacts on the Earth's resources and natural ecosystems [112, 113]. In order to feed such a large population, 100-110\% increase in global crop supply must be achieved by the middle of this century, which means that without the implementation of high-efficient agriculture, arable land area will have to increase by approximately 1 billion ha [114]. In order to achieve this, deforestation will be unavoidable $[115,116]$, which will cause a large number of forests to be converted into agricultural land and settlements [31, 117], and these land-use conversions will lead directly to plant habitat loss, which is the direct reason of plant extinction [18] (Fig. 2). Therefore, deforestation and land use change can be considered as the main and direct causes of plant extinction, whereas climate change and pollution are indirect (or possibly partly direct) causes of plant extinction [118]. It has been predicted that heavy metal and synthetic chemical pollution will change pollen morphology and physiological functions of plants, leading to the extinction of terrestrial plant species $[119,120]$, and excessive use of nitrogen and phosphorus fertilizers in agriculture leads to eutrophication and extinction of both terrestrial and aquatic plant species [121, 122].

In addition, fire [123] or outbreaks of pests [124] and invasive plants [125], which can be indirect effects of climate change, will also significantly increase the risk of plant extinction. The driving forces of plant extinction are not mutually exclusive $[14,126]$. For example, land use change is the result of deforestation, which can further enhance the effects of climate change because the deforested areas are more negatively influenced by unstable climate extremes than forested areas. Deforestation and the corresponding habitat loss are direct causes of plant extinction [126], but by the middle of this century, their negative impacts could be surpassed by the negative impacts of climate change [94]. But here, climate change, mainly means a warming climate, is 
supposed to have a more significant effect on plant speciation [24, 127]. However, the positive effect of climate change on plant speciation was greatly reduced and reversed by land use change, deforestation, and habitat loss. Therefore, in the Anthropocene, the rate of plant speciation is much lower than the rate of plant extinction [128]. In all, the primary cause of plant extinction is the uncontrolled exploitation of the Earth's resources in order to maintain human population growth and quality of life $[93,129,130]$.

\section{Conclusions and future perspectives}

Sustainable development of the human society is closely related to plant diversity [131]. Plant diversity directly determines wood production [132] and plants/vegetation resistance to pests and pathogens inherently [133]. In addition, plant diversity is also closely related to food security [134], diet nutrition [135], and human health and disease transmission [136, 137]. Therefore, maintaining plant diversity essentially means maintaining the sustainability of human society $[16,138]$. At present, only a few plant species are widely used as crops, and most plant species have great potential for unusual use [139], but we currently know very little about their status in the wild, especially for the plants inhabiting highest plant diversity areas, such as lowland tropics in Southeast Asia and the Amazon [14, 92]. As a consequence of the rapid increase in human population, habitat loss is almost inevitable [140], which could lead to plant extinction that would be no less in extent than the five major extinctions that occurred during the past, and this new extinction has already been termed as the "sixth mass extinction" [141-143]. As a consequence of the burning of large amounts of fossil fuels in a very short time, $\mathrm{CO}_{2}$ emissions and radiative force may exceed the highest levels in the past hundreds of millions of years [144]. It is difficult to conclude whether plants can quickly adapt to these environmental changes, but one thing is certain: because of the predatory exploitation of plant resources by human beings, plant diversity is unlikely to recover from this artificial mass extinction as well they did the past five times nor will the plants have the opportunity to undergo rapid speciation or evolve new plant species to fill ecological niches [145] as long as they are occupied by humans or crops $[129,146]$.

According to the simple principle of biodiversityenergy, it is inspired by a geological period, such as PETM of great biodiversity [8]. During this period, the climate is warm and humid, which is characterized by "crocodiles in the Arctic". The diversity of animals and plants was very high during PETM, and the angiosperms have undergone whole genome duplications, allowing them to dominate the terrestrial flora $[40-43,147,148]$. As the temperature of RCP 8.5 characterized by high emissions has many similarities with PETM [49], we speculate that climate warming in the twenty-first century will accelerate plant speciation via autopolyploidization [27, 28]. Although plant species turnover will be faster in this century than in the previous centuries, the rate of plant extinction caused directly by land use change and deforestation will be much higher than the rate of plant speciation accelerated by climate warming. Therefore, the risk of plant extinction in the Anthropocene is still very high.

We suggest several topics for future research: (i) Because rapid climate change and land use change will inevitably lead to the rapid evolution of some plants, it is important to study which plant traits are more likely to change, how they affect speciation and extinction, and what are their implications for conservation and plant adaptation [106, 149]. Implementing this kind of research in cities and botanical gardens may be the best choice; (ii) Polar regions face great direct and indirect pressures from the consequences of climate change and human exploitation. They are the outposts in response to climate change and we need to make good use of these natural laboratories to research the mechanisms of dispersion and invasion which cause plant speciation and extinction; (iii) It is also important to study how to maximize the conservation of plant genetics, species, and landscape and ecosystem diversity in the context of the development of human society and well-being [150]. Establishing a framework of "nature-social-health nexus" which incorporates the resilience of ecosystems, optimizes the efficiency of the framework by practice, and maximizes the sustainability of the human society is extremely important $[108,114]$; (iv) The aim of these researches would be to gain a holistic perspective on plant speciation and extinction. As today, speciation has been more researched from genetic or molecular perspectives, whereas extinction has been researched from ecological perspectives, we conclude that both views are needed to integrate plant evolution spatiotemporally.

\section{Supplementary information}

Supplementary information accompanies this paper at https://doi.org/10. 1186/s12870-020-02646-3.

Additional file 1: Figure S1. Relative search frequency of the terms "plant speciation" and "plant extinction" via Google (Google Trends). Time span from January 2004 to July 2019.

\footnotetext{
Acknowledgements

The authors thank Professor Pat Heslop-Harrison for his early encouragement when we are thinking about this topic (plant extinction vs. plant speciation) and his insightful discussions. Without the initiating article (DOl: https://doi. org/10.1093/aob/mcz174), there will be no this Review article. We apologize to colleagues whose excellent research on plant conservation and biodiversity could not be cited due to space limitations. We would like to thank Bright Gao and Dan Liu's company during the preparation of this article.
} 
Moreover, we are grateful for the helpful comments from the two anonymous reviewers.

\section{Authors' contributions}

JGG wrote the manuscript. HL, NW, JY \& XLZ have substantively revised this article. All the authors approved the submitted version of the manuscript.

\section{Funding}

This work was supported by the National Natural Science Foundation of China (31670411), the Pearl River S\&T Nova Program of Guangzhou (201806010083), and the Youth Innovation Promotion Association of the Chinese Academy of Sciences (2019339). None of the funding bodies were involved in the design of the study, analysis or interpretation of data or writing the manuscript.

\section{Availability of data and materials}

The datasets in this study are available from the corresponding author on reasonable request.

\section{Ethics approval and consent to participate}

There was no requirement to seek ethical approval to carry out the work described above.

\section{Consent for publication}

Not applicable.

\section{Competing interests}

The authors declare that they have no competing interests.

\section{Author details}

${ }^{1}$ Department of Ecology, College of Urban and Environmental Sciences, and Key Laboratory for Earth Surface Processes of the Ministry of Education, Peking University, No.5 Yiheyuan Road Haidian District, Beijing 100871, China. ${ }^{2}$ Key Laboratory of Vegetation Restoration and Management of Degraded Ecosystems, Chinese Academy of Sciences, 723 Xingke Road, Guangzhou 510650, China. ${ }^{3}$ State Key Laboratory of Plant Cell and Chromosome Engineering, Institute of Genetics and Developmental Biology, Chinese Academy of Sciences, Beijing 100101, China. ${ }^{4}$ State Key Laboratory of Genetic Engineering, Collaborative Innovation Center of Genetics and Development, Department of Biostatistics and Computational Biology, School of Life Sciences, Fudan University, Shanghai, China. ${ }^{5}$ Department of Public Policy, City University of Hong Kong, Tat Chee Avenue, Kowloon, Hong Kong, China.

Received: 27 March 2020 Accepted: 10 September 2020 Published online: 16 September 2020

\section{References}

1. Ibisch PL, Hoffmann MT, Kreft S, Pe'er G, Kati V, Biber-Freudenberger L, et al. A global map of roadless areas and their conservation status. Science. 2016; 354:1423-7. https://doi.org/10.1126/science.aaf7166.

2. Kleinschroth F, Laporte N, Laurance WF, Goetz SJ, Ghazoul J. Road expansion and persistence in forests of the Congo Basin. Nat Sustain. 2019; 2:628-34.

3. Hulme M, Barrow EM, Arnell NW, Harrison PA, Johns TC, Downing TE. Relative impacts of human-induced climate change and natural climate variability. Nature. 1999;397:688-91. https://doi.org/10.1038/17789.

4. Marvel K, Cook BI, Bonfils CJW, Durack PJ, Smerdon JE, Williams AP. Twentieth-century hydroclimate changes consistent with human influence. Nature. 2019;569:59-65. https://doi.org/10.1038/s41586-019-1149-8.

5. Zhang X, Zwiers FW, Hegerl GC, Lambert FH, Gillett NP, Solomon S, et al. Detection of human influence on twentieth-century precipitation trends. Nature. 2007:448:461-5. https://doi.org/10.1038/nature06025.

6. Palumbi SR. Humans as the World's greatest evolutionary force. Science. 2001;293:1786-90. https://doi.org/10.1126/science.293.5536.1786.

7. Gaynor KM, Hojnowski CE, Carter NH, Brashares JS. The influence of human disturbance on wildlife nocturnality. Science. 2018;360:1232-5. https://doi. org/10.1126/science.aar7121.

8. Erwin DH. Climate as a driver of evolutionary change. Curr Biol. 2009;19: R575-83. https://doi.org/10.1016/j.cub.2009.05.047.

9. Bull JW, Maron M. How humans drive speciation as well as extinction. Proc R Soc B Biol Sci. 2016;283:20160600.
10. Thackeray SJ, Henrys PA, Hemming D, Bell JR, Botham MS, Burthe S, et al. Phenological sensitivity to climate across taxa and trophic levels. Nature. 2016;535:241-5. https://doi.org/10.1038/nature18608.

11. Smith TB, Kinnison MT, Strauss SY, Fuller TL, Carroll SP. Prescriptive evolution to conserve and manage biodiversity. Annu Rev Ecol Evol Syst. 2014;45:122. https://doi.org/10.1146/annurev-ecolsys-120213-091747.

12. Doughty CE, Goulden ML. Are tropical forests near a high temperature threshold? J Geophys Res Biogeosciences. 2008;113:G00B07. https://doi.org/ 10.1029/2007JG000632.

13. Crous KY. Plant responses to climate warming: physiological adjustments and implications for plant functioning in a future, warmer world. Am J Bot. 2019;106:1049-51. https://doi.org/10.1002/ajb2.1329.

14. Corlett RT. Plant diversity in a changing world: status, trends, and conservation needs. Plant Divers. 2016;38:10-6. https://doi.org/10.1016/j.pld. 2016.01.001.

15. Mora C, Frazier AG, Longman RJ, Dacks RS, Walton MM, Tong EJ, et al. The projected timing of climate departure from recent variability. Nature. 2013; 502:183-7. https://doi.org/10.1038/nature12540.

16. Humphreys AM, Govaerts R, Ficinski SZ, Nic Lughadha E, Vorontsova MS Global dataset shows geography and life form predict modern plant extinction and rediscovery. Nat Ecol Evol. 2019;3:1043-7. https://doi.org/10. 1038/s41559-019-0906-2.

17. Loarie SR, Duffy PB, Hamilton H, Asner GP, Field CB, Ackerly DD. The velocity of climate change. Nature. 2009;462:1052-5. https://doi.org/10.1038/ nature08649.

18. Brummitt NA, Bachman SP, Griffiths-Lee J, Lutz M, Moat JF, Farjon A, et al. Green plants in the red: a baseline global assessment for the IUCN sampled red list index for plants. PLoS One. 2015;10:e0135152. https://doi.org/10. 1371/journal.pone.0135152.

19. Gao J, Tian K. Stem and leaf traits as co-determinants of canopy water flux. Plant Divers. 2019;41:258-65. https://doi.org/10.1016/j.pld.2019.06.003.

20. Smith BT, McCormack JE, Cuervo AM, Hickerson MJ, Aleixo A, Cadena CD, et al. The drivers of tropical speciation. Nature. 2014;515:406-9. https://doi. org/10.1038/nature13687.

21. Mannion PD, Upchurch P, Benson RBJ, Goswami A. The latitudinal biodiversity gradient through deep time. Trends Ecol Evol. 2014;29:42-50. https://doi.org/10.1016/j.tree.2013.09.012.

22. Saupe EE, Myers CE, Townsend Peterson A, Soberón J, Singarayer J, Valdes $P$, et al. Spatio-temporal climate change contributes to latitudinal diversity gradients. Nat Ecol Evol. 2019. https://doi.org/10.1038/s41559-019-0962-7.

23. Thomas CD. The Anthropocene could raise biological diversity. Nature. 2013;502:7.

24. Vellend M, Baeten L, Becker-Scarpitta A, Boucher-Lalonde V, McCune JL, Messier J, et al. Plant biodiversity change across scales during the Anthropocene. Annu Rev Plant Biol. 2017;68:563-86. https://doi.org/10.1146/ annurev-arplant-042916-040949.

25. Steinbauer MJ, Grytnes J-A, Jurasinski G, Kulonen A, Lenoir J, Pauli H, et al. Accelerated increase in plant species richness on mountain summits is linked to warming. Nature. 2018;556:231-4. https://doi.org/10.1038/s41586018-0005-6.

26. Suggitt AJ, Lister DG, Thomas CD. Widespread effects of climate change on local plant diversity. Curr Biol. 2019;29:2905-2911.e2. https://doi.org/10.1016/ j.cub.2019.06.079.

27. Levin DA. Plant speciation in the age of climate change. Ann Bot. 2019;124: 769-75. https://doi.org/10.1093/aob/mcz108.

28. Levin DA, Soltis DE. Factors promoting polyploid persistence and diversification and limiting diploid speciation during the K-Pg interlude. Curr Opin Plant Biol. 2018;42:1-7. https://doi.org/10.1016/j.pbi.2017.09.010.

29. Thomas CD. Rapid acceleration of plant speciation during the Anthropocene. Trends Ecol Evol. 2015;30:448-55. https://doi.org/10.1016/j. tree.2015.05.009

30. Watson A, Ghosh S, Williams MJ, Cuddy WS, Simmonds J, Rey M, et al. Speed breeding is a powerful tool to accelerate crop research and breeding. Nat Plants. 2018;4 January. https://doi.org/10.1038/s41477-017-0083-8..

31. Roberts P, Hunt C, Arroyo-Kalin M, Evans D, Boivin N. The deep human prehistory of global tropical forests and its relevance for modern conservation. Nat Plants. 2017;3:17093. https:/doi.org/10.1038/nplants.2017.93.

32. Milla R, Bastida JM, Turcotte MM, Jones G, Violle C, Osborne CP, et al. Phylogenetic patterns and phenotypic profiles of the species of plants and mammals farmed for food. Nat Ecol Evol. 2018;2:1808-17. https://doi.org/10. 1038/s41559-018-0690-4 
33. Salman-Minkov A, Sabath N, Mayrose I. Whole-genome duplication as a key factor in crop domestication. Nat Plants. 2016;2:16115. https://doi.org/10. 1038/nplants.2016.115

34. Lavania UC. Plant speciation and polyploidy: in habitat divergence and environmental perspective. Nucl. 2020;63:1-5. https://doi.org/10.1007/ s13237-020-00311-6.

35. Rice A, Šmarda P, Novosolov M, Drori M, Glick L, Sabath N, et al. The global biogeography of polyploid plants. Nat Ecol Evol. 2019;3:265-73. https://doi. org/10.1038/s41559-018-0787-9

36. Kagale S, Robinson SJ, Nixon J, Xiao R, Huebert T, Condie J, et al. Polyploid evolution of the Brassicaceae during the Cenozoic era. Plant Cell. 2014;26: 2777-91. https://doi.org/10.1105/tpc.114.126391.

37. Michel J-B, Shen YK, Aiden AP, Veres A, Gray MK, Pickett JP, et al. Quantitative analysis of culture using millions of digitized books. Science. 2011;331:176-82. https://doi.org/10.1126/science.1199644.

38. Van de Peer $Y$, Mizrachi E, Marchal K. The evolutionary significance of polyploidy. Nat Rev Genet. 2017;18:411-24. https://doi.org/10.1038/nrg.2017. 26.

39. Gao JG. Dominant plant speciation types. A commentary on: 'plant speciation in the age of climate change. Ann Bot. 2019;124:iv-vi. https://doi. org/10.1093/aob/mcz174.

40. Cai L, Xi Z, Amorim M, Sugumaran M, Rest JS, Liu L, et al. Widespread ancient whole-genome duplications in Malpighiales coincide with Eocene global climatic upheaval. New Phytol. 2019;221:565-76.

41. Mclnerney FA, Wing SL. The Paleocene-Eocene thermal maximum: a perturbation of carbon cycle, climate, and biosphere with implications for the future. Annu Rev Earth Planet Sci. 2011;39:489-516. https://doi.org/10. 1146/annurev-earth-040610-133431.

42. Zachos JC, Dickens GR, Zeebe RE. An early Cenozoic perspective on greenhouse warming and carbon-cycle dynamics. Nature. 2008;451:27983.

43. Jaramillo C, Ochoa D, Contreras L, Pagani M, Carvajal-Ortiz H, Pratt LM, et al. Effects of rapid global warming at the Paleocene-Eocene boundary on neotropical vegetation. Science. 2010;330:957-61.

44. Debodt S, Marre S, Vandepeer Y. Genome duplication and the origin of angiosperms. Trends Ecol Evol. 2005;20:591-7. https://doi.org/10.1016/j.tree. 2005.07.008.

45. Fawcett JA, Maere S, Van de Peer Y. Plants with double genomes might have had a better chance to survive the cretaceous-tertiary extinction event. Proc Natl Acad Sci. 2009;106:5737-42. https://doi.org/10.1073/pnas. 0900906106.

46. Clark JW, Donoghue PCJ. Constraining the timing of whole genome duplication in plant evolutionary history. Proc R Soc B Biol Sci. 2017:284:20170912. https://doi.org/10.1098/rspb.2017.0912.

47. Mandel JR, Dikow RB, Siniscalchi CM, Thapa R, Watson LE, Funk VA. A fully resolved backbone phylogeny reveals numerous dispersals and explosive diversifications throughout the history of Asteraceae. Proc Natl Acad Sci. 2019;116:14083-8. https://doi.org/10.1073/pnas.1903871116.

48. Lavania UC, Basu S, Kushwaha JS, Lavania S. Seasonal temperature variations influence tapetum mitosis patterns associated with reproductive fitness. Genome. 2014;57:517-21. https://doi.org/10.1139/gen-2014-0092.

49. Yao W, Paytan A, Wortmann UG. Large-Scale Ocean deoxygenation during the Paleocene-Eocene thermal maximum. Science. 2018;361:804-6. https:// doi.org/10.1126/science.aar8658.

50. Papadopulos AST, Igea J, Dunning LT, Osborne OG, Quan X, Pellicer J, et al. Ecological speciation in sympatric palms: 3. Genetic map reveals genomic islands underlying species divergence in Howea. Evolution. 2019;73:198695. https://doi.org/10.1111/evo.13796

51. Cleland EE, Chuine I, Menzel A, Mooney HA, Schwartz MD. Shifting plant phenology in response to global change. Trends Ecol Evol. 2007;22:357-65.

52. Horton DE, Johnson NC, Singh D, Swain DL, Rajaratnam B, Diffenbaugh NS. Contribution of changes in atmospheric circulation patterns to extreme temperature trends. Nature. 2015;522:465-9. https://doi.org/10.1038/ nature14550.

53. Geldmann J, Coad L, Barnes M, Craigie ID, Hockings M, Knights K, et al. Changes in protected area management effectiveness over time: a global analysis. Biol Conserv. 2015;191:692-9. https://doi.org/10.1016/j.biocon.2015.08.029.

54. Pearson RG. Reasons to conserve nature. Trends Ecol Evol. 2016;31:366-71. https://doi.org/10.1016/j.tree.2016.02.005.

55. Geldmann J, Barnes M, Coad L, Craigie ID, Hockings M, Burgess ND. Effectiveness of terrestrial protected areas in reducing habitat loss and population declines. Biol Conserv. 2013;161:230-8. https://doi.org/10.1016/j. biocon.2013.02.018.

56. Amano T, Székely T, Sandel B, Nagy S, Mundkur T, Langendoen T, et al. Successful conservation of global waterbird populations depends on effective governance. Nature. 2018;553:199-202. https://doi.org/10.1038/ nature25139.

57. Damschen El, Brudvig LA, Burt MA, Fletcher RJ, Haddad NM, Levey DJ, et al. Ongoing accumulation of plant diversity through habitat connectivity in an 18-year experiment. Science. 2019;365:1478-80. https://doi.org/10.1126/ science.aax8992.

58. Di Marco M, Ferrier S, Harwood TD, Hoskins AJ, Watson JEM. Wilderness areas halve the extinction risk of terrestrial biodiversity. Nature. 2019. https:// doi.org/10.1038/s41586-019-1567-7.

59. Watson JEM, Shanahan DF, Di Marco M, Allan J, Laurance WF, Sanderson EW, et al. Catastrophic declines in wilderness areas undermine global environment targets. Curr Biol. 2016;26:2929-34. https://doi.org/10.1016/j. cub.2016.08.049.

60. Estrada F, Botzen WJW, Tol RSJ. A global economic assessment of city policies to reduce climate change impacts. Nat Clim Chang. 2017;7:403-6. https://doi.org/10.1038/nclimate3301.

61. Ffrench-Constant RH, Somers-Yeates R, Bennie J, Economou T, Hodgson D, Spalding $A$, et al. Light pollution is associated with earlier tree budburst across the United Kingdom. Proc R Soc B Biol Sci. 2016;283:20160813.

62. Johnson MTJ, Munshi-South J. Evolution of life in urban environments. Science. 2017;358:eaam8327.

63. Calfapietra C, Peñuelas J, Niinemets Ü. Urban plant physiology: adaptationmitigation strategies under permanent stress. Trends Plant Sci. 2015;20:72-5 https://doi.org/10.1016/j.tplants.2014.11.001.

64. Givnish TJ. A New World of plants. Science. 2017;358:1535-6. https://doi. org/10.1126/science.aar4191.

65. Thompson KA, Rieseberg LH, Schluter D. Speciation and the City. Trends Ecol Evol. 2018;33:815-26. https://doi.org/10.1016/j.tree.2018.08.007.

66. Manoli G, Fatichi S, Schläpfer M, Yu K, Crowther TW, Meili N, et al. Magnitude of urban heat islands largely explained by climate and population. Nature. 2019;573:55-60. https://doi.org/10.1038/s41586-019-1512-9.

67. Aronson MFJ, La Sorte FA, Nilon CH, Katti M, Goddard MA, Lepczyk CA, et al. A global analysis of the impacts of urbanization on bird and plant diversity reveals key anthropogenic drivers. Proc R Soc B Biol Sci. 2014;281: 20133330. https://doi.org/10.1098/rspb.2013.3330.

68. Hahs AK, McDonnell MJ, McCarthy MA, Vesk PA, Corlett RT, Norton BA, et al. A global synthesis of plant extinction rates in urban areas. Ecol Lett. 2009;12: 1165-73. https://doi.org/10.1111/j.1461-0248.2009.01372.x.

69. Holland MM, Bitz CM. Polar amplification of climate change in coupled models. Clim Dyn. 2003;21:221-32. https://doi.org/10.1007/s00382-003-0332-6.

70. Comiso JC, Hall DK. Climate trends in the Arctic as observed from space. Wiley Interdiscip Rev Clim Chang. 2014;5:389-409. https://doi.org/10.1002/ wcc.277.

71. IPCC. IPCC Special Report on the Ocean and Cryosphere in a Changing Climate. 2019. https://www.ipcc.ch/srocc/download-report-2/. Accessed 1 Mar 2020

72. Post E, Alley RB, Christensen TR, Macias-Fauria M, Forbes BC, Gooseff MN, et al. The polar regions in a $2^{\circ} \mathrm{C}$ warmer world. Sci Adv. 2019;5:eaaw9883. https://doi.org/10.1126/sciadv.aaw9883.

73. Wang M, Overland JE. A sea ice free summer Arctic within 30 years: an update from CMIP5 models. Geophys Res Lett. 2012;39:L18501. https://doi. org/10.1029/2012GL052868.

74. Ibarbalz FM, Henry N, Brandão MC, Martini S, Busseni G, Byrne H, et al. Global trends in marine plankton diversity across kingdoms of life. Cell. 2019;179:1084-1097.e21. https://doi.org/10.1016/j.cell.2019.10.008.

75. Macias-Fauria M, Forbes BC, Zetterberg P, Kumpula T. Eurasian Arctic greening reveals teleconnections and the potential for structurally novel ecosystems. Nat Clim Chang. 2012;2:613-8. https://doi.org/10.1038/ nclimate1558

76. Anesio AM, Laybourn-Parry J. Glaciers and ice sheets as a biome. Trends Ecol Evol. 2012;27:219-25. https://doi.org/10.1016/j.tree.2011.09.012.

77. Lu L-M, Mao L-F, Yang T, Ye J-F, Liu B, Li H-L, et al. Evolutionary history of the angiosperm flora of China. Nature. 2018;554:234-8. https://doi.org/10. 1038/nature25485.

78. Kapfer J, Virtanen R, Grytnes J-A. Changes in arctic vegetation on Jan Mayen Island over 19 and 80 years. J Veg Sci. 2012;23:771-81. https://doi.org/10. 1111/j.1654-1103.2012.01395.x. 
79. Clem KR, Fogt RL, Turner J, Lintner BR, Marshall GJ, Miller JR, et al. Record warming at the South pole during the past three decades. Nat Clim Chang. 2020;10:762-70. https://doi.org/10.1038/s41558-020-0815-z.

80. Stammerjohn SE, Scambos TA. Warming reaches the South pole. Nat Clim Chang. 2020;10:710-1. https://doi.org/10.1038/s41558-020-0827-8.

81. Maurer JM, Schaefer JM, Rupper S, Corley A. Acceleration of ice loss across the Himalayas over the past 40 years. Sci Adv. 2019;5:eaav7266. https://doi. org/10.1126/sciadv.aav7266.

82. Ulloa Ulloa C, Acevedo-Rodríguez P, Beck S, Belgrano MJ, Bernal R, Berry PE, et al. An integrated assessment of the vascular plant species of the Americas. Science. 2017;358:1614-7. https://doi.org/10.1126/science.aao0398.

83. Teixeira da Silva JA, Kerbauy GB, Zeng S, Chen Z, Duan J. In vitro flowering of orchids. Crit Rev Biotechnol. 2014;34:56-76. https://doi.org/10.3109/ 07388551.2013 .807219

84. Ma Y, Marczewski T, Xue D, Wu Z, Liao R, Sun W, et al. Conservation implications of asymmetric introgression and reproductive barriers in a rare primrose species. BMC Plant Biol. 2019;19:286. https://doi.org/10.1186/ s12870-019-1881-0.

85. Mallet J. Hybrid speciation. Nature. 2007;446:279-83. https://doi.org/10.1038/ nature05706.

86. Soltis PS, Soltis DE. The role of hybridization in plant speciation. Annu Rev Plant Biol. 2009;60:561-88. https://doi.org/10.1146/annurev.arplant.043008. 092039.

87. Vallejo-Marín M, Hiscock SJ. Hybridization and hybrid speciation under global change. New Phytol. 2016;211:1170-87.

88. Taylor SA, Larson EL. Insights from genomes into the evolutionary importance and prevalence of hybridization in nature. Nat Ecol Evol. 2019;3: 170-7. https://doi.org/10.1038/s41559-018-0777-y.

89. Mounce R, Smith P, Brockington S. Ex situ conservation of plant diversity in the world's botanic gardens. Nat Plants. 2017;3:795-802. https://doi.org/10. 1038/s41477-017-0019-3.

90. Primack RB, Miller-Rushing AJ. The role of botanical gardens in climate change research. New Phytol. 2009;182:303-13. https://doi.org/10.1111/j. 1469-8137.2009.02800.x.

91. Nowak H, Schneebeli-Hermann E, Kustatscher E. No mass extinction for land plants at the Permian-Triassic transition. Nat Commun. 2019;10:384. https:// doi.org/10.1038/s41467-018-07945-w.

92. Pimm SL, Joppa LN. How many plant species are there, where are they, and at what rate are they going extinct? Ann Missouri Bot Gard. 2015;100:170-6. https://doi.org/10.3417/2012018.

93. Marques A, Martins IS, Kastner T, Plutzar C, Theurl MC, Eisenmenger N, et al. Increasing impacts of land use on biodiversity and carbon sequestration driven by population and economic growth. Nat Ecol Evol. 2019;3:628-37. https://doi.org/10.1038/s41559-019-0824-3.

94. Gomes VHF, Vieira ICG, Salomão RP, ter Steege H. Amazonian tree species threatened by deforestation and climate change. Nat Clim Chang. 2019;9: 547-53. https://doi.org/10.1038/s41558-019-0500-2

95. Ledford $\mathrm{H}$. World's largest plant survey reveals alarming extinction rate. Nature. 2019:570:148-9. https://doi.org/10.1038/d41586-019-01810-6.

96. Sánchez-Bayo F, Wyckhuys KAG. Worldwide decline of the entomofauna: a review of its drivers. Biol Conserv. 2019;232:8-27.

97. Hamabata T, Kinoshita G, Kurita K, Cao P-L, Ito M, Murata J, et al. Endangered island endemic plants have vulnerable genomes. Commun Biol. 2019;2:244. https://doi.org/10.1038/s42003-019-0490-7.

98. Woodroffe R. Edge effects and the extinction of populations inside protected areas. Science. 1998;280:2126-8. https://doi.org/10.1126/science. 280.5372.2126.

99. Koh LP. Species Coextinctions and the biodiversity crisis. Science. 2004;305: 1632-4. https://doi.org/10.1126/science.1101101.

100. Klein A-M, Vaissière BE, Cane JH, Steffan-Dewenter I, Cunningham SA, Kremen C, et al. Importance of pollinators in changing landscapes for world crops. Proc R Soc B Biol Sci. 2007;274:303-13. https://doi.org/10.1098/rspb.2006.3721.

101. Kessler SC, Tiedeken EJ, Simcock KL, Derveau S, Mitchell J, Softley S, et al. Bees prefer foods containing neonicotinoid pesticides. Nature. 2015;521:746. https://doi.org/10.1038/nature14414.

102. Rundlöf M, Andersson GKS, Bommarco R, Fries I, Hederström V, Herbertsson $L$, et al. Seed coating with a neonicotinoid insecticide negatively affects wild bees. Nature. 2015;521:77-80. https://doi.org/10.1038/nature14420.

103. Tsvetkov N, Samson-Robert O, Sood K, Patel HS, Malena DA, Gajiwala PH, et al. Chronic exposure to neonicotinoids reduces honey bee health near corn crops. Science. 2017;356:1395-7. https:/doi.org/10.1126/science.aam7470.
104. Rosenberg KV, Dokter AM, Blancher PJ, Sauer JR, Smith AC, Smith PA, et al. Decline of the North American avifauna. Science. 2019:eaaw1313. https:// doi.org/10.1126/science.aaw1313.

105. Eng ML, Stutchbury BJM, Morrissey CA. A neonicotinoid insecticide reduces fueling and delays migration in songbirds. Science. 2019;365:1177-80. https://doi.org/10.1126/science.aaw9419.

106. Chase JM, Blowes SA, Knight TM, Gerstner K, May F. Ecosystem decay exacerbates biodiversity loss with habitat loss. Nature. 2020. https://doi.org/ 10.1038/s41586-020-2531-2.

107. Lewinsohn TM, Cagnolo L. Keystones in a tangled Bank. Science. 2012;335: 1449-51. https://doi.org/10.1126/science.1220138.

108. Perino A, Pereira HM, Navarro LM, Fernández N, Bullock JM, Ceaușu S, et al. Rewilding complex ecosystems. Science. 2019;364:eaav5570. https://doi.org/ 10.1126/science.aav5570.

109. Krauss SL, Phillips RD, Karron JD, Johnson SD, Roberts DG, Hopper SD. Nove consequences of bird pollination for plant mating. Trends Plant Sci. 2017;22: 395-410. https://doi.org/10.1016/j.tplants.2017.03.005.

110. Forman RTT, Wu J. Where to put the next billion people. Nature. 2016;537: 608-11. https://doi.org/10.1038/537608a.

111. Gerland P, Raftery AE, ev ikova H, Li N, Gu D, Spoorenberg T, et al. World population stabilization unlikely this century. Science. 2014;346:234-7. https://doi.org/10.1126/science.1257469.

112. Green RE. Farming and the fate of wild nature. Science. 2005;307:550-5. https://doi.org/10.1126/science.1106049.

113. Krausmann F, Schandl H, Eisenmenger N, Giljum S, Jackson T. Material flow accounting: measuring global material use for sustainable development. Annu Rev Environ Resour. 2017;42:647-75. https://doi.org/10.1146/annurevenviron-102016-060726.

114. Tilman D, Balzer C, Hill J, Befort BL. Global food demand and the sustainable intensification of agriculture. Proc Natl Acad Sci. 2011;108:20260-4. https:// doi.org/10.1073/pnas.1116437108.

115. Fuller TL, Narins TP, Nackoney J, Bonebrake TC, Sesink Clee P, Morgan K, et al. Assessing the impact of China's timber industry on Congo Basin land use change. Area. 2019;51:340-9.

116. Newbold T. The trouble with trade. Nat Ecol Evol. 2019;3:522-3. https://doi. org/10.1038/s41559-019-0816-3.

117. Curtis PG, Slay CM, Harris NL, Tyukavina A, Hansen MC. Classifying drivers of global forest loss. Science. 2018;361:1108-11. https://doi.org/10.1126/ science.aau3445.

118. Isbell F, Reich PB, Tilman D, Hobbie SE, Polasky S, Binder S. Nutrient enrichment, biodiversity loss, and consequent declines in ecosystem productivity. Proc Natl Acad Sci. 2013;110:11911-6. https://doi.org/10.1073/ pnas.1310880110

119. Patra M, Sharma A. Mercury toxicity in plants. Bot Rev. 2000;66:379-422.

120. Bernhardt ES, Rosi EJ, Gessner MO. Synthetic chemicals as agents of global change. Front Ecol Environ. 2017;15:84-90. https://doi.org/10.1002/fee.1450.

121. Clark CM, Tilman D. Loss of plant species after chronic low-level nitrogen deposition to prairie grasslands. Nature. 2008:451:712-5. https://doi.org/10. 1038/nature06503.

122. Steffen W, Richardson K, Rockstrom J, Cornell SE, Fetzer I, Bennett EM, et al. Planetary boundaries: guiding human development on a changing planet. Science. 2015;347:1259855. https://doi.org/10.1126/science.1259855.

123. Jolly WM, Cochrane MA, Freeborn PH, Holden ZA, Brown TJ, Williamson GJ, et al. Climate-induced variations in global wildfire danger from 1979 to 2013. Nat Commun. 2015;6:7537. https://doi.org/10.1038/ncomms8537.

124. Boyd IL, Freer-Smith PH, Gilligan CA, Godfray HCJ. The consequence of tree pests and diseases for ecosystem services. Science. 2013;342:1235773. https://doi.org/10.1126/science.1235773.

125. Bradley BA, Wilcove DS, Oppenheimer M. Climate change increases risk of plant invasion in the eastern United States. Biol Invasions. 2010;12:1855-72. https://doi.org/10.1007/s10530-009-9597-y.

126. Barlow J, Lennox GD, Ferreira J, Berenguer E, Lees AC, Mac NR, et al. Anthropogenic disturbance in tropical forests can double biodiversity loss from deforestation. Nature. 2016;535:144-7. https://doi.org/10.1038/nature18326.

127. Urban MC. Accelerating extinction risk from climate change. Science. 2015; 348:571-3. https://doi.org/10.1126/science.aaa4984.

128. Tilman D, Lehman C. Human-caused environmental change: impacts on plant diversity and evolution. Proc Natl Acad Sci. 2001;98:5433-40. https:// doi.org/10.1073/pnas.091093198.

129. Tollefson J. Humans are driving one million species to extinction. Nature. 2019. https://doi.org/10.1038/d41586-019-01448-4. 
130. Crist E, Mora C, Engelman R. The interaction of human population, food production, and biodiversity protection. Science. 2017;356:260-4. https://doi. org/10.1126/science.aal2011.

131. Isbell F, Gonzalez A, Loreau M, Cowles J, Díaz S, Hector A, et al. Linking the influence and dependence of people on biodiversity across scales. Nature. 2017;546:65-72.

132. Liang J, Crowther TW, Picard N, Wiser S, Zhou M, Alberti G, et al. Positive biodiversity-productivity relationship predominant in global forests. Science. 2016;354:aff857. https://doi.org/10.1126/science.aaf8957.

133. Laforest-Lapointe I, Paquette A, Messier C, Kembel SW. Leaf bacterial diversity mediates plant diversity and ecosystem function relationships. Nature. 2017;546:145-7. https://doi.org/10.1038/nature22399.

134. Springmann M, Clark M, Mason-D'Croz D, Wiebe K, Bodirsky BL, Lassaletta L, et al. Options for keeping the food system within environmental limits. Nature. 2018;562:519-25. https://doi.org/10.1038/s41586-018-0594-0.

135. Rasolofoson RA, Hanauer MM, Pappinen A, Fisher B, Ricketts TH. Impacts of forests on children's diet in rural areas across 27 developing countries. Sci Adv. 2018;4:eaat2853. https://doi.org/10.1126/sciadv.aat2853.

136. Morris AL, Guégan J-F, Andreou D, Marsollier L, Carolan K, Le Croller M, et al. Deforestation-driven food-web collapse linked to emerging tropical infectious disease, Mycobacterium ulcerans. Sci Adv. 2016;2:e1600387. https:// doi.org/10.1126/sciadv.1600387.

137. Wilkinson DA, Marshall JC, French NP, Hayman DTS. Habitat fragmentation, biodiversity loss and the risk of novel infectious disease emergence. J R Soc Interface. 2018;15:20180403. https://doi.org/10.1098/rsif.2018.0403.

138. Watson JEM, Evans T, Venter O, Williams B, Tulloch A, Stewart C, et al. The exceptional value of intact forest ecosystems. Nat Ecol Evol. 2018;2:599-610. https://doi.org/10.1038/s41559-018-0490-x.

139. Castañeda-Álvarez NP, Khoury CK, Achicanoy HA, Bernau V, Dempewolf H, Eastwood RJ, et al. Global conservation priorities for crop wild relatives. Nat Plants. 2016;2:16022. https://doi.org/10.1038/nplants.2016.22.

140. Foley J. Living by the lessons of the planet. Science. 2017;356:251-2. https:// doi.org/10.1126/science.aal4863.

141. Barnosky AD, Matzke N, Tomiya S, Wogan GOU, Swartz B, Quental TB, et al. Has the Earth's sixth mass extinction already arrived? Nature. 2011;471:51-7. https://doi.org/10.1038/nature09678.

142. Ceballos G, Ehrlich PR, Barnosky AD, García A, Pringle RM, Palmer TM. Accelerated modern human-induced species losses: entering the sixth mass extinction. Sci Adv. 2015;1:e1400253. https://doi.org/10.1126/sciadv. 1400253.

143. Ceballos G, Ehrlich PR, Dirzo R. Biological annihilation via the ongoing sixth mass extinction signaled by vertebrate population losses and declines. Proc Natl Acad Sci. 2017;1 14:E6089-96. https://doi.org/10.1073/pnas.1704949114.

144. Foster GL, Royer DL, Lunt DJ. Future climate forcing potentially without precedent in the last 420 million years. Nat Commun. 2017;8:14845. https:// doi.org/10.1038/ncomms14845.

145. Lowery CM, Bralower TJ, Owens JD, Rodríguez-tovar FJ, Jones H, Smit J, et al. Rapid recovery of life at ground zero of the end-cretaceous mass extinction. Nature. 2018;558:288-97.

146. Stephens L, Fuller D, Boivin N, Rick T, Gauthier N, Kay A, et al. Archaeological assessment reveals Earth's early transformation through land use. Science. 2019;365:897-902. https://doi.org/10.1126/science.aax1192.

147. Wilf P, Labandeira CC. Response of plant-insect associations to PaleoceneEocene warming. Science. 1999;284:2153-6.

148. Currano ED, Wilf P, Wing SL, Labandeira CC, Lovelock EC, Royer DL. Sharply increased insect herbivory during the Paleocene-Eocene thermal maximum. Proc Natl Acad Sci. 2008;105:1960-4. https://doi.org/10.1073/pnas. 0708646105.

149. Hortal J, Santos AMC. Rethinking extinctions that arise from habitat loss. Nature. 2020. https://doi.org/10.1038/d41586-020-02210-X.

150. Ripple WJ, Wolf C, Newsome TM, Galetti M, Alamgir M, Crist E, et al. World scientists' warning to humanity: a second notice. Bioscience. 2017;67:10268. https://doi.org/10.1093/biosci/bix125.

\section{Publisher's Note}

Springer Nature remains neutral with regard to jurisdictional claims in published maps and institutional affiliations.

Ready to submit your research? Choose BMC and benefit from:

- fast, convenient online submission

- thorough peer review by experienced researchers in your field

- rapid publication on acceptance

- support for research data, including large and complex data types

- gold Open Access which fosters wider collaboration and increased citations

- maximum visibility for your research: over $100 \mathrm{M}$ website views per year

At BMC, research is always in progress.

Learn more biomedcentral.com/submissions 